\title{
Characterization of novel pneumatic mixing for single-use bioreactor application
}

\author{
Brian Lee ${ }^{1 *}$, David Fang ${ }^{2}$, Matthew Croughan ${ }^{3}$, Manuel Carrondo ${ }^{4}$, Sang-Hoon Paik ${ }^{5}$ \\ From 22nd European Society for Animal Cell Technology (ESACT) Meeting on Cell Based Technologies \\ Vienna, Austria. 15-18 May 2011
}

\section{Background}

The novel bioreactor system from PBS Biotech ${ }^{\circledR}$ is the first with a pneumatic mixing device powered solely by gas buoyancy, eliminating the need for an external mechanical agitator. The patented design of the AirWheel mixing device promotes not only high tangential fluid flow around the wheel but also efficient radial and axial flows. The leverage effect of the Air-Wheel mixing device also allows for lower gassing requirement $(\mathrm{v} / \mathrm{v})$ with increasing working volume, making the power utilization from the gas buoyancy more efficient with scale.

A series of physical tests were performed to demonstrate that PBS systems can promote uniform, homogenous mixing over a wide range of working volumes and can offer a low-shear environment for cell culture. A series of biological tests were then performed at various evaluation sites to confirm the physical test results.

\section{Results}

Mixing time was calculated in PBS systems ranging from $2 \mathrm{~L}$ to $5,000 \mathrm{~L}$ working volume by measuring the change in conductivity readings from bolus additions of concentrated salt solution. 95\% mixing times were found to be between $20 \mathrm{sec}$ and $62 \mathrm{sec}$ over this range of working volumes in the PBS systems (Table 1), significantly shorter than reported values in conventional stirred tank systems.

Shear stress and turbulent kinetic energy dissipation rate $\left(\varepsilon\right.$, in $\left.\mathrm{m}^{2} / \mathrm{s}^{3}\right)$ were calculated from computational fluid dynamics (CFD) modeling on Star CCM+ software. Lower average shear stress $\left(\tau_{\mathrm{avg}}\right.$, in $\left.\mathrm{Pa}\right)$ on the impeller and lower average energy dissipation rate $\left(\varepsilon\right.$, in $\left.\mathrm{m}^{2} / \mathrm{s}^{3}\right)$ in the impeller region were found in the PBS system

\footnotetext{
* Correspondence: blee@pbsbiotech.com

'PBS Biotech Inc., Camarillo, California, 93012, USA

Full list of author information is available at the end of the article
}

compared to stirred-tank bioreactors at typical impeller speeds at the respective working volumes. Comparably low level of shear stress $(<0.5 \mathrm{~Pa})$ was found in the PBS system ranging from $3 \mathrm{~L}$ to $2,500 \mathrm{~L}$ working volume, and the uniformity of mixing in the PBS system was confirmed with the consistency of $\varepsilon\left(<0.01 \mathrm{~m}^{2} / \mathrm{s}^{3}\right)$ over the same broad range of working volumes.

At Keck Graduate Institute, lactate-adapted $\mathrm{CHO}$ DG44 cells were cultured in fed-batch mode in $3 \mathrm{~L}$ and 15L PBS systems using $\mathrm{CD}$ OptiCHO ${ }^{\mathrm{TM}}$ medium from Invitrogen ${ }^{\mathrm{TM}}$. Comparable peak viable cell density of $25 \times 10^{6} \mathrm{cell} / \mathrm{mL}$ was attained in both systems, and $>90 \%$ viability was maintained through 12 days of culture.

At IBET, Sf9 insect cells were infected with baculovirus expressing enhanced green fluorescent protein (eGFP) in a 3L PBS system. Infection with the baculovirus was performed at MOI of 0.8 on day 1 of the run. Successful expansion of baculovirus in Sf9 cells was demonstrated by high level of eGFP expression and infected particles detected after day 1.

At Green Cross Corporation, a process for producing Fc-fusion protein was run in the 250L PBS system in parallel with the 300L (220L w.v.) stirred-tank bioreactor in fed-batch mode over a span of 19 days. Superior peak viable cell density and product titer were achieved in the PBS system compared to the stirred-tank system (Figure 1). Protein physical methods (reduced PAGE and IEF), ELISA, and in-vitro bioactivity assay (MTS cell inhibition assay) revealed equivalence of products made in PBS and stirred-tank systems.

Table $195 \%$ mixing time from $2 \mathrm{~L}$ to $5,000 \mathrm{~L}$ working volumes in PBS prototype units

\begin{tabular}{ccccccc}
\hline & $2 \mathrm{~L}$ & $10 \mathrm{~L}$ & $50 \mathrm{~L}$ & $250 \mathrm{~L}$ & $1,000 \mathrm{~L}$ & $5,000 \mathrm{~L}$ \\
\hline Gas Flow Rate (WM) & 0.07 & 0.06 & 0.05 & 0.04 & 0.03 & 0.02 \\
Mixing Time (sec) & 20 & 25 & 30 & 38 & 53 & 62 \\
\hline
\end{tabular}

(c) 2011 Lee et al; licensee BioMed Central Ltd. This is an open access article distributed under the terms of the Creative Commons 

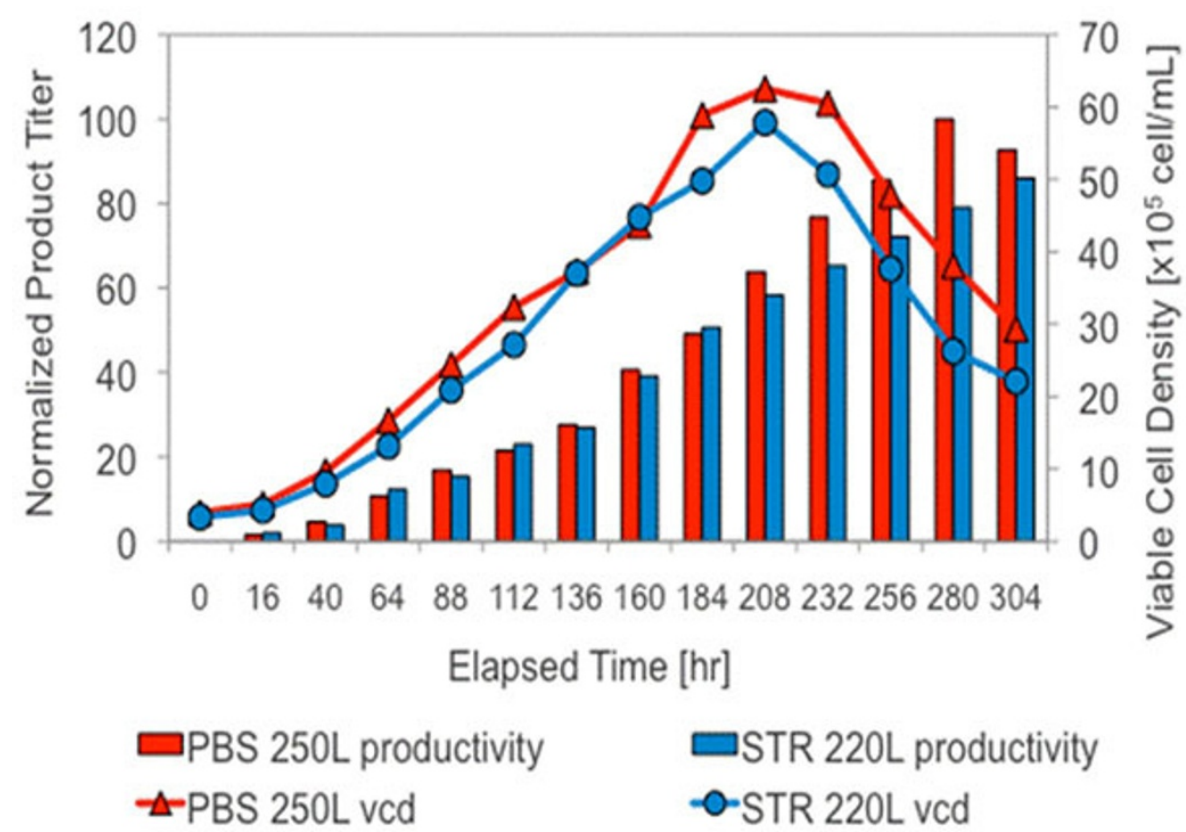

Figure 1 Viable cell density and product titer comparison between 250L PBS bioreactor and 220L stainless steel bioreactor for an Fc-fusion protein

\section{Conclusions}

CFD modeling results revealed uniform, homogenous mixing pattern with low-shear stress in PBS systems over a wide range of working volumes. Short mixing times from conductivity-based mixing tests confirmed the efficiency of mixing in PBS systems.

Recent biological studies performed at beta test sites further demonstrated successful performance in three key tests:

1) Scalable growth for a high cell density process in $3 \mathrm{~L}$ and 15L PBS systems,

2) Successful baculovirus expansion in insect cells in the $3 \mathrm{~L}$ PBS system, and

3) Comparable growth and product performance in the 250L PBS system against a 220L stirred-tank bioreactor using a Fc-fusion protein-producing process.

\section{Acknowledgments}

PBS Biotech thanks Life Technologies ${ }^{T M}$ for their generous contribution of cell culture medium for our study at KGl.

\section{Author details}

${ }^{1}$ PBS Biotech Inc., Camarillo, California, 93012, USA. ²Systems QbD, Newbury Park, California, 91320, USA. ${ }^{3}$ Keck Graduate Institute (KGI), Claremont, California, 91711, USA. ${ }^{4}$ Instituto de Biologia Experimental e Tecnologica (IBET), Lisbon, 2780-157, Portugal. ${ }^{5}$ Green Cross Corp., Yongin-Si, KyungGi-Do, 449-070, South Korea.

Published: 22 November 2011
doi:10.1186/1753-6561-5-S8-012

Cite this article as: Lee et al:: Characterization of novel pneumatic mixing for single-use bioreactor application. BMC Proceedings 20115 (Suppl 8):012.
Submit your next manuscript to BioMed Central and take full advantage of:

- Convenient online submission

- Thorough peer review

- No space constraints or color figure charges

- Immediate publication on acceptance

- Inclusion in PubMed, CAS, Scopus and Google Scholar

- Research which is freely available for redistribution 